\title{
The Relationship between Brand Trust, Brand Affect, Attitudinal Loyalty and Behavioral Loyalty: A Field Study towards Sports Shoe Consumers in Turkey
}

\author{
Fatih Geçti ${ }^{1}$ \& Hayrettin Zengin ${ }^{2}$ \\ ${ }^{1}$ Faculty of Economics and Administrative Sciences, Yalova University, Turkey \\ ${ }^{2}$ Faculty of Business, Sakarya University, Turkey \\ Correspondence: Fatih Geçti, Department of Management, Faculty of Economics and Administrative Sciences, \\ Yalova University, Safran Campus, 77100, Yalova, Turkey. E-mail: fgecti@yalova.edu.tr
}

\author{
Received: February 5, 2013 Accepted: February 16, 2013 Online Published: February 28, 2013 \\ doi:10.5539/ijms.v5n2p111 URL: http://dx.doi.org/10.5539/ijms.v5n2p111
}

\begin{abstract}
The main purpose of this study is to examine the relations between brand trust, brand affect, attitudinal loyalty and behavioral loyalty. In this regard, an online survey was conducted on sports shoe consumers in Turkey. 428 consumers participated in the survey which has been open for two months on the relevant web page. Hypotheses, which were proposed within the framework of the research model, were tested with structural equation modeling. The results indicate that there is a positive relation between brand trust and brand affect. Brand trust is also positively related to both attitudinal loyalty and behavioral loyalty. Contrary to expectations, brand affect exerted no significant impact on behavioral loyalty.
\end{abstract}

Keywords: brand trust, brand affect, attitudinal loyalty, behavioral loyalty, sports shoe

\section{Introduction}

To date, brand loyalty concept has been a quite important issue in several points for most of the enterprises. Some researchers suggested that the brand loyalty routinize the consumers's purchase of the brand and it is a force that resist the consumer's shift to other brand. Thus; it can be said that the value of the brand increases as much as the customer loyalty to the brand. Because; the most significant aim of creating brand value is to ensure the flow of the brand loyal customers (Yoo et al., 2000; Travis, 2000).

When marketing literature is reviewed; there are several researches which review the determinants of brand loyalty concept and the factors that affect it (Beerli et al., 2004; Kim \& Yoon, 2004; Jensen \& Hansen, 2006; Consuegra et al., 2007). The great interest of the researchers to the brand loyalty concept is based on the fact that the brand loyalty is a quite important concept in both theoratical context and especially for the pragmatists.

Although there is not a common consensus on the method for how to measure the brand loyalty; when the relevant literature is reviewed, it is seen that measurements for the brand loyalty is usually classified under two categories namely as attitudinal and behavioral measurements and therefore it is understood that the loyalty is a dimensional concept (Thiele \& Bennett, 2001). There are several factors that influence the consumers' attitudinal and/or behavioral loyalty towards the brand.

In this study; concentrating upon brand trust and brand affect, the roles of these factors on brand loyalty has been discussed. Besides the direct impact of brand trust and brand affect on attitudinal and behavioral loyalty, also the mediator impact of brand affect on the relation between brand trust and brand loyalty has been analysed. In addition, the relation between attitudinal and behavioral loyalty has been examined. In this context; the current study aims to examine the relations between brand loyalty, brand affect, attitudinal loyalty and behavioral loyalty. It is thought that the analysis on the relations between these four structures will have a conceptual contribution to the relevant literature and provide different insights about brand loyalty concept.

\section{Literature Review and Hypotheses}

Figure 1 shows the research model developed for the context of the relations between brand trust, brand affect, attitudinal loyalty and behavioral loyalty. 


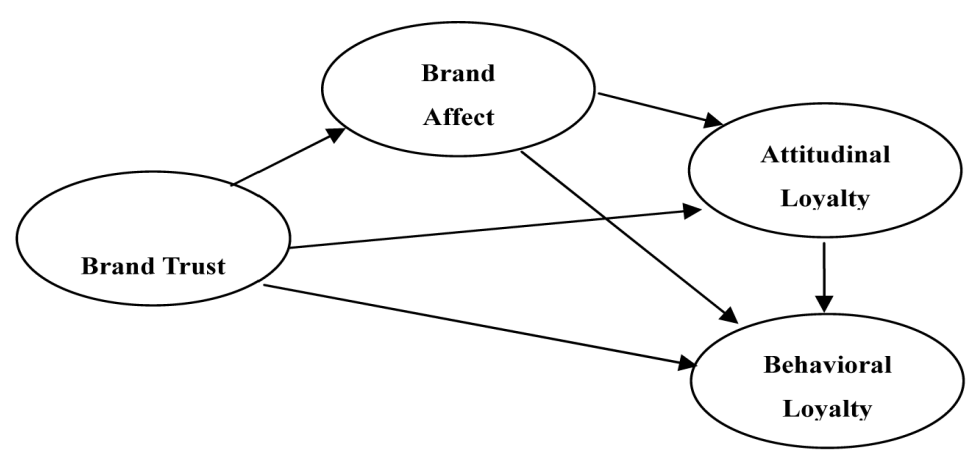

Figure 1. Research model (proposed model)

\subsection{Brand Trust}

In the literature, there are several studies on brand trust (Lau \& Lee ,1999; Ballester \& Aleman, 2001; Harris \& Goode, 2004; Ballester \& Aleman, 2005; Kim et al., 2008; Mohammad, 2012). It is stated that brand trust is an important mediator factor on the customer behaviors before and after the purchase of the product ; and it causes long term loyalty and strengthens the relation between two parties (Liu et al, 2011). Brand trust can be defined as the willingness of the average consumer to rely on the ability of the brand to perform its stated functions (Chaudhuri \& Holbrook, 2001:82).

Despite that the brand affect is more spontaneous, immediate and is realized with less consideration; brand trust covers a well thought, designed and considered process (Chaudhuri \& Holbrook, 2001). Even if there is a difference between brand trust and brand affect when the processes are considered; brand trust is one of the significant variables that has an impact on brand affect (Chaudhuri \& Holbrook, 2001; Halim, 2006; Sung \& Kim, 2010).

One of the most important factors which directly influences brand loyalty is brand trust. The impact of the trust on loyalty becomes exclusively relevant and important in case of decision taken for changing the brand due to high level of perceived risk and obscurity (Ibanez et al., 2006). Trust plays a key role in increasing brand loyalty and also has an impact on the factors such as sustaining market share and price flexibility which are related with marketing results (Gommans et al., 2001).

In most of the studies; brand loyalty is measured and evaluated in respect of two categories namely as attitudinal loyalty and behavioral loyalty. There are studies which explain the significant impacts of brand trust both on attitudinal loyalty and behavioral loyalty (Matzler et al, 2006; Matzler et al., 2008; Anuwitchanont, 2011; Ok et al., 2011; Hanzaee \& Andervazh, 2012).

Based on the above discussion, the hypotheses are developed as follows;

$\mathrm{H} 1$ : Brand trust has a positive effect on brand affect.

$\mathrm{H} 2$ : Brand trust has a positive effect on attitudinal loyalty.

$\mathrm{H} 3$ : Brand trust has a positive effect on behavioral loyalty.

\subsection{Brand Affect}

Brand affect describes the relations between consumers and brand under certain category and it can be considered as the general evaluations of the consumers for brand (Matzler et al., 2006). Brand affect can be defined as a brand's potential to elicit a positive emotional response in the average consumer as a result of its use (Chaudhuri \& Holbrook, 2001:82). It is stated that under the conditions when the brand affect is much, brand loyalty also needs to be higher (Dick \& Basu, 1994).

Considering the creation of brand relations and its sustainability, it is stated that brand affect should be considered as an important antecedent of brand loyalty (Matzler et al., 2006). When the relevant literature is reviewed; it can be seen that there are several studies revealing the relations between brand affect and brand loyalty. These studies discusses that brand affect has meaningful impacts on attitudinal and behavioral brand loyalty (Taylor et al., 2004; Matzler et al., 2008; Jahangir et al., 2009).

Thus, the hypotheses are proposed as follows; 
H4: Brand affect has a positive effect on attitudinal loyalty.

H5: Brand affect has a positive effect on behavioral loyalty.

\subsection{Attitudinal Loyalty}

Attitudinal loyalty approaches brand loyalty mostly as an attitude and focuses on the psychological commitment of the consumer (Odin et al., 2001). Attitudinal loyalty concept refers to consumers' deal with the intensive problem solving behavior that covers the brand and feature comparisons and leads to strong brand preferences (Bennett \& Thiele, 2002). Within this context; attitudinal loyalty is an analysis of the consumer attitudes that include the consumer's psychological loyalty for the brand (Quester \& Lim, 2003). Measurements for attitudinal loyalty use the attitudinal data which indicate the affective and psychological factors within the structure of brand loyalty and it is stated that these measurements are related with the commitment and loyalty feelings (Bowen \& Chen, 2001).

It is said that there is a relation between attitudinal loyalty and behavioral loyalty. While Bennett \& Thiele (2002) discussed that behavioral loyalty is an observable result of attitudinal loyalty; Thiele \& Mackay (2001) discussed that the correlation between attitudinal and behavioral loyalty should be positive. Also some reviews on the issue revealed that there is a relation between attitudinal and behavioural loyalty (Chaudhuri \& Holbrook, 2001; Halim, 2006; Carpenter , 2008; Huang \& Zhang, 2008).

Therefore, the hypothesis is proposed as follows;

H6: Attitudinal loyalty has a positive effect on behavioral loyalty.

\subsection{Behavioral Loyalty}

Behavioral loyalty considers brand loyalty as a behavior. The person who buys a certain brand continuously is loyal to this brand (Odin et al., 2001). Behavioral loyalty can be defined as a behavior that is shown by a consumer to a brand within the form of repeated purchases (Back \& Parks, 2003:420). However; behavioral measurement are insufficient to explain how and why the brand loyalty develops on the consumer (Dick \& Basu, 1994) and they do not enable the study to reveal whether the repeated purchase arise from situational reasons or different complicated psychological causes other than habitual actions (Odin et al., 2001). Behavioral loyalty can be described as purchase loyalty as well.

\section{Method}

\subsection{Purpose of the Study}

The purpose of this study is to explain the relations between brand trust, brand affect and brand loyalty. As stated in the previous section, brand loyalty concept is measured under two different dimensions namely as attitudinal brand loyalty and behavioral brand loyalty. In this context, the main problematic of the study is to reveal the role of brand trust and brand affect on attitudinal and behavioural brand loyalty and to analyse the relations between these structures.

\subsection{Sample and Data Collection}

The population of the research includes all of the sports shoe consumers in Turkey. Due to some restrictions such as time, cost and difficulty to reach all the population, the study has been limited with the sample. As there is no sample framework for the consumers who use the relevant product; convenience sampling method has been used in the study. Data have been collected via an online survey launched in internet between September-October 2012. 428 consumers participated in the survey used for the study.

\subsection{Product Selection}

As a product category, sports shoe has been used in the current research. There are several reasons for selecting this product. Almost everybody around us use one sports shoe brand and their level of awareness and interest towards this product is relatively high. Besides; today, sports shoes have been indispensable for the consumers; especially for the young ones; due to the comfort they ensure. Moreover, these product do not only provide functional benefits but also they are able to provide psychological benefits. Hence; during the selection of these products, besides the trust for the brand also the affective factors can come to the forefront. Within this context; it can be said that the sports shoe brands have the potential to impose both brand trust and brand affect on the consumer.

\subsection{Scales}

The questionnaire used for the research contains two sections. In the first section, there is demographic information related with the sample. In the second section, there are scales used for testing the research model. Five-point Likert type scales ( $1=$ Strongly Disagree ... 5=Strongly Agree) have been used in the survey. 
Chaudhuri \& Holbrook's (2001) scale has been adapted to measure brand trust and brand affect. Attitudinal and behavioral loyalty have been measured by Halim's (2006) scale.

\subsection{Analysis Method}

Proposed hypotheses have been tested with the structural equation modeling. In this regard, SPSS and AMOS programs have used for data analysis.

\section{Results}

\subsection{Participant Profile}

Demographic features of the participants are shown in Table 1.

Table 1. Demographic features of the participants $(\mathrm{n}=428)$

\begin{tabular}{llllll}
\hline & $\mathrm{n}$ & $\%$ & & $\mathrm{n}$ & $\%$ \\
\hline Gender & & & Occupation & & \\
Male & 175 & 40.9 & Civil Servant & 60 & 14 \\
Female & 253 & 59.1 & Retired & 1 & 0.2 \\
Marital Status & & & House Wife & 9 & 2.1 \\
Married & 81 & 18.9 & Student & 145 & 33.9 \\
Single & 347 & 81.1 & Worker & 10 & 2.3 \\
Age & & & Self-Employment & 17 & 4 \\
Under 20 & 20 & 4.7 & Unemployed & 55 & 12.9 \\
$21-30$ & 352 & 82.2 & Private Sector Employee & 111 & 25.9 \\
$31-40$ & 48 & 11.2 & Tradesman & 4 & 0.9 \\
41-50 & 7 & 1.6 & Others & 16 & 3.7 \\
Over 51 & 1 & 0.2 & Income Level & & \\
Education Level & & & Less Than 1000 Turkish Lira (TL) & 191 & 44.6 \\
Secondary Education & 81 & 18.9 & 1000-2000 TL & 148 & 34.6 \\
Bachelor Degree & 287 & 67.1 & 2001-3000 TL & 133 & 13.8 \\
Graduate School & 60 & 14 & 3001-4000 TL & 34 & 2.6 \\
& & & More Than 4000 TL & 19 & 4.4 \\
\hline
\end{tabular}

Most of the participants are female (59.1\%), single $(81.1 \%)$, the ones between the ages of $21-30,(82.2 \%)$, university graduates $(67.1 \%)$, students and private sector employees $(59.8 \%)$ and the ones whose income level is under $2000 \mathrm{TL}(79.2 \%)$.

\subsection{Validity and Reliability Analysis}

Before applying to structural equation modeling, measurement model has been tested with Anderson \& Gerbing's (1988) two-stage approach. The latent variables in the measurement model are respectively brand trust, brand affect, attitudinal loyalty and behavioral loyalty. The measurement model has provided the acceptable fit statistics $\left({ }^{2} / \mathrm{df}=4.2 ; \mathrm{GFI}=.92 ; \mathrm{AGFI}=.87 ; \mathrm{TLI}=.94 ; \mathrm{CFI}=.95 ; \mathrm{RMSEA}=.08\right)$. Validity and reliability analysis related with the measurement model are demonstrated in Table 2.

Table 2. Item measurement properties

\begin{tabular}{lllll}
\hline Scale/Items & $\begin{array}{l}\text { Standart } \\
\text { Loadings }\end{array}$ & $\begin{array}{l}\text { Composite } \\
\text { Reliability } \\
\text { (CR) }\end{array}$ & $\begin{array}{l}\text { Average } \\
\text { Variance } \\
\text { Extracted } \\
\text { (AVE) }\end{array}$ & $\begin{array}{l}\text { Cronbach } \\
\text { Alfa }\end{array}$ \\
\hline BRAND TRUST & .80 & .90 & .75 & .89 \\
$\begin{array}{l}\text { BT1 (I trust this brand) } \\
\text { BT2 (This brand is safe) }\end{array}$ & .96 & & & \\
BT3 (This is an honest brand) & .83 & .88 & .72 & .88 \\
BRAND AFFECT & .81 & & & \\
BA1 (This brand gives me pleasure) & .91 & & & \\
BA2 (This brand makes me happy) & .91 & & \\
BA3 (I feel good when I use this & .81 & & & \\
brand) & & & & \\
\hline
\end{tabular}




\begin{tabular}{|c|c|c|c|c|}
\hline ATTITUDINAL LOYALTY & & .88 & .71 & .87 \\
\hline $\begin{array}{l}\text { AL1 (I will not switch to other brand } \\
\text { even though there are lots of other } \\
\text { brand options) }\end{array}$ & .75 & & & \\
\hline $\begin{array}{l}\text { AL2 (I am willing to pay more than } \\
\text { any other brand to get this particular } \\
\text { brand) }\end{array}$ & .89 & & & \\
\hline AL3 (I will always use this brand) & .88 & & & \\
\hline BEHAVIORAL LOYALTY & & .85 & .66 & .83 \\
\hline $\begin{array}{l}\text { BL1 (I will buy this brand in the } \\
\text { future) }\end{array}$ & .69 & & & \\
\hline $\begin{array}{l}\text { BL2 (I will fulfill the everlasting } \\
\text { purchasing will over this brand) }\end{array}$ & .93 & & & \\
\hline $\begin{array}{l}\text { BL3 (I wish to continue purchasing } \\
\text { over this brand) }\end{array}$ & .80 & & & \\
\hline
\end{tabular}

Confirmatory factor analysis loads of the brand trust variable have ranged from .80 and .96 . Composite reliability (CR) value related with the factor is .90; and average variance extracted (AVE) is .75 and cronbach alfa value is .89. Confirmatory factor analysis loads related with brand affect variable have ranged from .81 and .91 . CR value related with the factor is .88 , AVE value is .72 and cronbach alfa value is .88. Confirmatory factor analysis loads related with the attitudinal loyalty variable have ranged from .75 and .89 . CR value related with the factor is .88 , AVE value is .81 and conbach alfa value is .87 . Confirmatory factor analysis loads of the behavioral loyalty factor have ranged from .69 and .93 . CR value of this factor is .85 , AVE value is .66 and cronbach alfa value is .83 .

As both the fit indices and item loads of each factor are high in acceptable levels (>.69); it can be said that convergent validity is ensured for the dimensions used in the measurement model. Discriminant validity has been calculated using the AVE results that are between .66 and .75 . AVE values exceeded the square of phi estimates for the constructs, providing disciminant validity. Thus, all factors in the model are in different structure from each other and discriminant validity was ensured (Anderson \& Gerbing, 1988; Fornell \& Larcker, 1981). Thus; it is possible to say that the measurement model is valid and reliable.

Correlations among the constructs in research model is shown in Table 3.

Table 3. Correlations among constructs

\begin{tabular}{lllll}
\hline Constructs & 1 & 2 & 3 & 4 \\
\hline 1- Brand Trust & 1.00 & & & \\
2- Brand Affect & .70 & 1.00 & & \\
3- Attitudinal Loyalty & .47 & .54 & 1.00 & \\
4- Behavioral Loyalty & .64 & .60 & .92 & 1.00 \\
\hline
\end{tabular}

According to the Table 3, correlation values between the structures in the model have ranged from .47 and .92 .

\subsection{Structural Model and Hypotheses Test}

In order to test the hypotheses of the research; structural equation modeling has been used. Structural model is shown in Figure 2. 


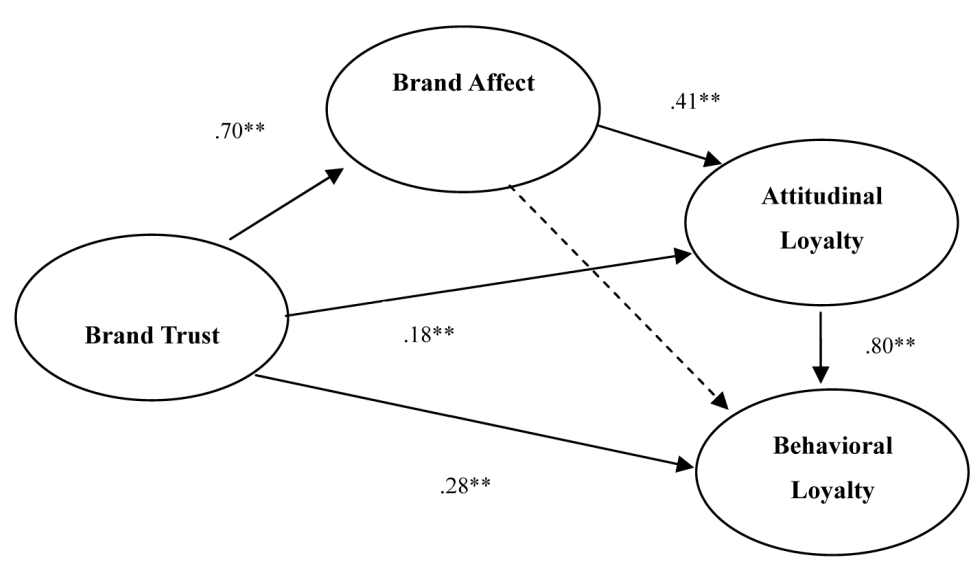

Figure 2. Structural model

Note. $* * \mathrm{p}<.001$

Fit statistics of the structural model are indicated in Table 4.

Table 4. Structural model fit statistics

\begin{tabular}{ccccccc}
\hline & \multicolumn{7}{c}{ Fit Index } \\
\cline { 2 - 7 } Structural & $\chi^{2} / \mathrm{df}$ & GFI & AGFI & TLI & CFI & RMSEA \\
\cline { 2 - 7 } Model & 4.3 & .93 & .88 & .94 & .96 & .08 \\
\hline $\mathrm{R}^{2}$ (Brand Affect) $=.48$ & & & & \\
$\mathrm{R}^{2}$ (Attitudinal Loyalty) $=.31$ & & & & \\
$\mathrm{R}^{2}$ (Behavioral Loyalty) $=.90$ & & & & \\
\hline
\end{tabular}

According to the Table 4, it is seen that all the fit indices related with the structural model are within an acceptable levels. Also, it is revealed that the brand affect factor in the model explains variance in the ratio of .48, attitudinal loyalty factor explains .31 and behavioral loyalty factor explains .90 .

Results of the hypotheses in the research model are shown in Table 5.

Table 5. Results of hypothesis test

\begin{tabular}{|c|c|c|c|c|c|c|}
\hline \multicolumn{3}{|c|}{ Hypothesized Path } & $\overline{\mathrm{St}}$ & t-Value & Sig. & Result \\
\hline H1:Brand Trust & $\rightarrow$ & Brand Affect & .70 & 13.368 & $* * *$ & Supported \\
\hline $\mathrm{H}_{2}$ : Brand Trust & $\rightarrow$ & Attitudinal Loyalty & .18 & 2.589 & .010 & Supported \\
\hline H3: Brand Trust & $\rightarrow$ & Behavioral Loyalty & .28 & 5.543 & $* * *$ & Supported \\
\hline H4: Brand Affect & $\rightarrow$ & Attitudinal Loyalty & .41 & 5.625 & $* * *$ & Supported \\
\hline H5: Brand Affect & $\rightarrow$ & Behavioral Loyalty & -.03 & -.483 & .629 & Rejected \\
\hline H6: Attitudinal Loyalty & $\rightarrow$ & Behavioral Loyalty & .80 & 14.053 & $* * *$ & Supported \\
\hline
\end{tabular}

Note. ${ }^{* * *} \mathrm{p}<.001$

Table 5 indicates that $\mathrm{H} 1$ hypothesis, which suggests that brand trust has a positive effect on brand affect, is accepted $(\beta=.70 ; \mathrm{t}=13.368 ; \mathrm{p}<.001) . \mathrm{H} 2$ hypthesis, which suggests that brand trust has a positive effect on attitudinal loyalty, is also accepted $(\beta=.18 ; \mathrm{t}=2.589 ; \mathrm{p}<.05$ ). In a similar way; $\mathrm{H} 3$ hypothesis, which suggests that there is a positive relation between brand trust and behavioral loyalty, is supported ( $\beta=.28 ; \mathrm{t}=5.543 ; \mathrm{p}$ $<.001)$. A positive relation between brand affect and attitudinal loyalty is revealed and $\mathrm{H} 4$ hypothesis is also accepted $(\beta=.41 ; \mathrm{t}=5.625 ; \mathrm{p}<.001)$. Statistically, it is seen that brand affect has no significant effect on behavioral loyalty. Hence $\mathrm{H} 5$ hypothesis is rejected $(\beta=-.03 ; \mathrm{t}=-.483 ; \mathrm{p}>.05)$. The last hypothesis of the research (H6) indicates that attitudinal loyalty has a positive effect on behavioral loyalty. This hypothesis is also 
supported $(\beta=.80 ; \mathrm{t}=14.053 ; \mathrm{p}<.001)$.

The direct, indirect and total effects on the dependent variables in the research model are shown in Table 6 .

Table 6. Direct and indirect effects

\begin{tabular}{lccc}
\hline & Brand Trust & Brand Affect & Attitudinal Loyalty \\
\hline Total Effect & & & \\
Brand Affect & .70 & - & - \\
Attitudinal Loyalty & .47 & .41 & - \\
Behavioral Loyalty & .64 & .31 & .80 \\
Direct Effect & & & \\
Brand Affect & .70 & - & - \\
Attitudinal Loyalty & .18 & .41 & - \\
Behavioral Loyalty & .28 & -.03 & .80 \\
Indirect Effect & & & - \\
Brand Affect & - & - & - \\
Attitudinal Loyalty & .29 & - & - \\
Behavioral Loyalty & .36 & .33 & \\
\hline
\end{tabular}

According to Table 6 , attitudinal loyalty is the most effective variable on behavioral loyalty $(\beta=.80)$. Concerning the direct effects; brand trust has .70 impact on brand affect, .18 on attitudinal loyalty and .28 on behavioral loyalty. Brand affect has direct effect only on attitudinal loyalty (.41). Considering the indirect effects; compared to the attitudinal loyalty, brand trust is much more effective on behavioral loyalty (.36). Although the brand affect has no significant and direct impact on behavioral loyalty; by means of attitudinal loyalty, it has an indirect impact of 33 .

\section{Conclusion and Discussion}

In this study, the relations between brand trust, brand affect, attitudinal loyalty and behavioral loyalty have been analysed. First of all, the validity and reliability analysis of the measurement model has been applied in the study. Once the validity and reliability of the measurement model has been confirmed, the relations between the latent variables in the model have been tested with structural equation model.

Analysing the relation between brand trust and brand affect, it has been concluded that brand trust has a quite important impact on brand affect. It is also seen that this result supports the findings in the relevant literature (Chaudhuri \& Holbrook, 2001; Halim, 2006; Sung \& Kim, 2010). In this context, it is possible to say that a consumer, who has trust for the sport shoe brand he/she uses, has also a positive affective reaction for this brand at the same time.

Concerning the relation between brand trust and brand loyalty, brand trust is positively related to both on attitudinal and behavioral loyalty. But; brand trust is much more influential on behavioral loyalty. In addition, brand trust is effective on attitudinal loyalty with the mediation of brand affect. It is seen that brand loyalty increases as brand trust increases and this result also supports the literature (Gommans et al.,2001; Matzler et al, 2006; Matzler et al., 2008; Anuwitchanont, 2011; Ok et al., 2011; Liu et al, 2011).

In contrast with the findings of Chaudhuri \& Holbrook (2001) where brand affect positively influences attitudinal and behavioral loyalty, this study's findings showed that brand affect has no significant effect on behavioral loyalty. Thus, we have assumed that brand affect does not make a meaningful difference for sports shoe consumers' behavioral loyalty.

Literature related to consumer research mention that attitude is a factor that leads to behavior. With this study, it has been suggested that attitudinal loyalty has a positive and strong impact on behavioral loyalty. In this context, it can be suggested that this result agrees with Chaudhuri \& Holbrook (2001), Halim (2006), Carpenter (2008) and Huang \& Zhang (2008) demonstrating that attitudinal loyalty influences behavioral loyalty.

\section{Limitations and Future Studies}

This study has been concluded within the framework of three limitations. The first limitation of the study is that the research is also conducted on sports shoe consumers. Besides, results of the research have been obtained by an online survey method. Similar to the other online surveys, the sample in this study includes only the ones who are willing to answer the questions in the survey and this causes the second limitation. Also, as the psychological states 
and the conditions of the participants are not known, the reliability of the answers can also be questionable. The last limitation of the study is the preference of convenience sampling method. Due to the difficulty to reach all the population subject to the research, convenience sampling method has been chosen. But; it is not possible for the sample to represent all population. Thus, generalization may not be made.

Upon this study; there may be some suggestions for further studies. The scope of this research is consumers who use sports shoes in Turkey. Considering this fact; for the future studies, products from different categories and consumers from different countries may be chosen and comparative studies might be carried out. In addition, there may be studies which include both the product and the service. Moderator effects of the variables such as age, gender, income level on brand trust, brand affect and loyalty can also be the subject of future studies. Furthermore, more complicated models, which include the relations between brand trust, brand affect and the other antedecedents of brand loyalty might be examined.

\section{References}

Anderson, J. C., \& Gerbing, D. W. (1988). Structural equation modeling in practice: A review and recommended two step aproach. Psychological Bulletin, 103(3), 411-423. http://dx.doi.org/10.1037/0033-2909.103.3.411

Anuwichhanont, J. (2011). The impact of price perception on customer loyalty in the airline context. Journal of Business\& Economics Research, 9(9), 37-49.

Back, K. J., \& Parks, S. C. (2003). A brand loyalty model involving cognitive, affective, and conative brand loyalty and customer satisfaction. Journal of Hospitality \& Tourism Research, 27(4), 419-435. http://dx.doi.org/10.1177/10963480030274003

Ballester, E. D., \& Aleman, J. L. M. (2001). Brand trust in the context of consumer loyalty. European Journal of Marketing, 35(11/12), 1238-1258. http://dx.doi.org/10.1108/EUM0000000006475

Ballester, E. D., \& Aleman, J. L. M. (2005). Does brand trust matter to brand equity? Journal of Product \& Brand Management, 14(3), 287-296.

Beerli, A., Martin, J. D., \& Quintana, A. (2004). A model of customer loyalty in the retail banking market. European Journal of Marketing, 38(1/2), 253-275. http://dx.doi.org/10.1108/03090560410511221

Bennett, R., \& Thiele, S. R. (2002). A comparison of attitudinal loyalty measurement approaches. Journal of Brand Management, 9(3), 193-209. http://dx.doi.org/10.1057/palgrave.bm.2540069

Bowen, J. T., \& Chen, S. (2001). The relationship between customer loyalty and customer satisfaction. International Journal of Contemporary Hospitality Management, 13(5), 213-217. http://dx.doi.org/10.1108/09596110110395893

Carpenter, J. M. (2008). Consumer shopping value, satisfaction and loyalty in discount retailing. Journal of Retailing and Consumer Services, 15(5), 358-363. http://dx.doi.org/10.1016/j.jretconser.2007.08.003

Chaudhuri, A., \& Holbrook, M. B. (2001). The chain of effects from brand trust and brand affect to brand performance: The role of brand loyalty. Journal of Marketing, 65(2), 81-93. http://dx.doi.org/10.1509/jmkg.65.2.81.18255

Consuegra, D. M., Molina, A., \& Esteban, A. (2007). An integrated model of price, satisfaction and loyalty: An empirical analysis in the service sector. Journal of Product \& Brand Management, 16(7), 459-468. http://dx.doi.org/10.1108/10610420710834913

Dick, A. S., \& Basu, K. (1994). Customer loyalty: Toward an integrated conceptual framework. Journal of the Academy of Marketing Science, 22(2), 99-113. http://dx.doi.org/10.1177/0092070394222001

Fornell, C., \& Larcker, D. F. (1981). Evaluating structural equation models with unobservable variables and measurement errors. Journal of Marketing Research, 18(1), 39-50. http://dx.doi.org/10.2307/3151312

Gommans, M., Krishnan, K. S., \& Scheffold, K. B. (2001). From brand loyalty to e-loyalty: A conceptual framework. Journal of Economic and Social Research, 3(1), 43-58.

Halim, R. E. (2006). The effect of the relationship of brand trust and brand affect on brand performance: An analysis from brand loyalty perspective- A case of coffee instant product in Indonesia. Retrieved from $\mathrm{http}: / /$ ssrn.com/abstract $=925169$

Hanzaee, K. H., \& Andervazh, L. (2012). An analysis of some moderating variables on the value, brand trust and brand loyalty chain. Research Journal Applied Sciences, Engineering and Technology, 4(10), 1403-1413.

Harris, L. C., \& Goode, M. M. H. (2004). The four levels of loyalty and the pivatal role of trust: A study of 
online service dynamics. Journal of Retailing, 80, 139-158. http://dx.doi.org/10.1016/j.jretai.2004.04.002

Huang, J., \& Zhang, D. (2008). Customer value and brand loyalty: Multi-dimensional empirical test. International Seminar on Future Information Technology and Management Engineering, 102-106.

Ibanez, V. A., Hartmann, P., \& Calvo, P. Z. (2006). Antecedents of customer loyalty in residential energy markets: service quality, satisfaction, trust and switching costs. The Service Industries Journal, 26(6), 633-650. http://dx.doi.org/10.1080/02642060600850717

Jahangir, N., Parvez, N., Bhattacharjee, D., \& Ahamed, K. K. (2009). The relationship between brand affect, brand quality, and customers' brand extension attitude: Exploring the mediating role of customer loyalty. The Cambodian Management Journal, 1(1), 20-34.

Jensen, J. M., \& Hansen, T. (2006). An Empirical Examination Of Brand Loyalty. Journal of Product \& Brand Management, 15(7), 442-449. http://dx.doi.org/10.1108/10610420610712829

Kim, H. S., \& Yoon, C. H. (2004). Determinants of subscriber churn and customer loyalty in the Korean mobile telephony market. Telecommunications Policy, 28, 751-765. http://dx.doi.org/10.1016/j.telpol.2004.05.013

Kim, K. H., Kim, K. S., Kim, D. Y., Kim, J. H., \& Kang, S. H. (2008). Brand equity in hospital marketing. Journal of Business Research, 61, 75-82. http://dx.doi.org/10.1016/j.jbusres.2006.05.010

Lau, G., \& Lee, S. H. (1999). Consumers' trust in a brand and the link to brand loyalty. Journal of Market Focused Management, 4, 341-370. http://dx.doi.org/10.1023/A:1009886520142

Liu, C. T., Guo, Y. M., \& Le, C. H. (2011). The effects of relationship quality and switching barriers on customer loyalty. International Journal of Information Management, 31, 71-79. http://dx.doi.org/10.1016/j.ijinfomgt.2010.05.008

Matzler, K., Krauter, S. G., \& Bidmon, S. (2006). Individual determinants of brand affect: The role of the personality traits of extraversion and openness to experience. Journal of Product \& Brand Management, 15(7), 427-434. http://dx.doi.org/10.1108/10610420610712801

Matzler, K., Krauter, S. G., \& Bidmon, S. (2008). Risk aversion and brand loyalty: The mediating role of brand trust and brand affect. Journal of Product \& Brand Management, 17(3), 154-162. http://dx.doi.org/10.1108/10610420810875070

Mohammad, A. A. S. (2012). The effect of brand trust and perceived value in building brand loyalty. International Research Journal of Finance and Economics, 85, 111-126.

Odin, Y., Odin, N., \& Florence, P. V. (2001). Conceptual and operational aspects of brand loyalty: An empirical $\begin{array}{llll}\text { investigation. Journal of Business } & \text { Research, }\end{array}$ http://dx.doi.org/10.1016/S0148-2963(99)00076-4

Ok, C., Choi, Y. G., \& Hyun, S. S. (2011). Roles of brand value perceptions in the development of brand credibility and brand prestige. ICHRIE Conference Refereed Track, University of Massachusetts, 1-8.

Quester, P., \& Lim, A. L. (2003). Product involvement/brand loyalty: Is there a link? Journal of Product \& Brand Management, 12(1), 22-38. http://dx.doi.org/10.1108/10610420310463117

Sung, Y., \& Kim, J. (2008). Effects of brand personality on brand trust and brand affect. Psychology \& Marketing, 27(7), 639-661. http://dx.doi.org/10.1002/mar.20349

Taylor, S. A., Celuch, K., \& Goodwin, S. (2004). The importance of brand equity to customer loyalty. Journal of Product \& Brand Management, 13(4), 217-227. http://dx.doi.org/10.1108/10610420410546934

Thiele, S. R., \& Bennett, R. (2001). A brand for all seasons? A discussion of brand loyalty approaches and their applicability for different markets. Journal of Product and Brand Management, 10(1), 25-37. http://dx.doi.org/10.1108/10610420110382803

Thiele, S. R., \& Mackay, M. M. (2001). Assessing the performance of brand loyalty measures. Journal of Services Marketing, 15(7), 529-541. http://dx.doi.org/10.1108/EUM0000000006210

Travis, D. (2000). Emotional branding: How successful brands gain the irrational edge. California, USA: Prima Publishing.

Yoo, B., Donthu, N., \& Lee, S. (2000). An examination of selected marketing mix elements and brand equity. Journal of the Academy of Marketing Science, 28(2), 195-211. http://dx.doi.org/10.1177/0092070300282002 